school buildings, a description of necessary equipments for medical examination, danger signals of defects, and other points relative to the matter of school and personal hygiene. The chapter dealing with dental conditions in elementary school children, should prove of special value. The investigation of some tens of thoussands of records of school children in this country have proved that the average child having decayed teeth, several cavities, requires something over five months longer to complete their elementary school course than do those children not affected this way. Children with painful teeth chew their food less effectively, in many cases eat less also, in either case a fundamental factor in nutrition has been interfered with, the ultimate results being a lessened vigor. I cite this as an example of the importance of dental inspection as well as the medical examination.

The chapter on open air schools is of sufficient interest to create a desire for the possible establishment of more of this kind of institutions. This is the preventive medicine exemplified, and the excellent results obtained point to the influence the open air school promises to bring to bear on elementary education in general.

The appended bibliographies to each chapter are comprehensive, and, for assistance to those desiring further study will prove of practical value.

At present practically every state in the union has laws dealing with medical examination of schools, but in many cases the child is examined and the diagnosis filed away for future reference and nothing actually happens to the child. There are not enough doctors to give sufficient examinations and there are not enough nurses to see that the prescriptions of the doctors are carried out. If this volume aids in the correcting of the fault which lies behind the trouble in America-the inadequate salaries paid-it will have served as a means to an excellent end, in this country if no further.

LUTHer H. GULıcK. ${ }^{1}$

\title{
A MUNICIPAL NEWSPAPER
}

7 HE Los Angeles Municipal News is a weekly, 12-page newspaper of ordinary newspaper size and appearance, published by the city of Los Angeles. Sixty thousand copies are printed in each weekly edition and distributed free throughout the city.

In its news columns the paper confines itself almost entirely to news items relating to the city government, but not exclusively so; its news field being limited rather by the discretion of the commission in charge then by any hard and fast rules governing its publication. Municipal news is featured in the paper by being given the prominent positions and the big headlines.

1 The Department of Child Hygiene of the Russell Sage Foundation. 
The editorial policy of the paper follows the official policies of the city, as the same have been determined by the city charter, and express vote of the people, or by city ordinance. The editorial policy of the paper is instructive and descriptive, rather than argumentative or exhortatory.

When any municipal question is actively under discussion before the people, that is to say, before the official policy of the city has been determined in the matter, The Los Angeles Municipal News appoints two special writers, each of whom writes a special column-one on each side of the question under discussion-and the two columns are published side by side properly headlined as the arguments for and against. The two special writers, though appointed and paid by the paper, each consult freely with the friends of the side of the controversy which they represent, and in a very large measure present the arguments for that side in accordance with the wishes of the leading proponents thereof. This provision for a hearing for each side of active public questions is one of the most highly appreciated features of the paper.

Each political party, whether national or local, that polls 3 per cent of the vote of the city at any regular election, is allowed the free use of one column in each issue of The Los Angeles Municipal News. In these columns, each carrying appropriate headlines to indicate the respective parties to which they belong, the political parties are allowed to express their positions on public questions in their own way, free from any censorship whatsoever by the management of the paper, excepting that the matter published in the columns must be lawful for publication. The city administration or the newspaper itself may be freely criticized in these party columns. At the present time there are five of these party columns, to wit: Republican, Democratic, Socialist, Socialist-Labor and Good Government. Some of the parties use their columns only for the discussion of national or state questions, and refrain from taking any part in the discussion of municipal issues, and some visa versa; while others set no such limitations upon themselves.

The Los Angeles Municipal News accepts ordinary commercial advertising of approved classes. As illustrating the kinds of advertising that are barred, the paper will accept no medical advertisements, no advertisements of stocks and bonds that are not listed on a regular stock exchange unless the same have paid dividends regularly for the past three years, and no liquor advertisements.

The voters of Los Angeles established The Los Angeles Municipal News by a very large majority vote on an initiative ordinance creating the newspaper, which ordinance was submitted to a popular vote at the regular city election in December, 1911. The voters sought to establish a paper which would have three leading characteristics: 
1. It should give prominence to municipal matters and not allow them to be side-tracked for the sensations of the day.

2. It should publish the municipal news accurately, not coloring its news columns with bias of any kind.

3. It should make ample provision for the publication of the arguments on each side of live public questions.

The feeling of the voters was strong that the affairs of the city were altogether too much in the hands of the privately owned newspapers, whose news columns often contained bias, and whose editorials displayed a onesided advocacy.

The scheme of The Los Angeles Municipal News, above outlined, has been regarded by some as the extreme of ridiculous foolishness, and by others as possessing almost immeasurable potentialities for municipal betterment.

At the time of the writing of this article, five issues of the paper have been printed. Owing to limited financial resources, the typographical appearance of the paper is not as yet first class, but is gradually improving. Its reception by the voters of the city has been, on the whole, favorable, and the friends of the enterprise are unshaken in the confidence that it has a field to fill and is sure to succeed.

The original plan contemplated a 40,000 edition of an 8-page paper; but all issues so far have been of 60,000 12-page papers. This enlargement of the original plans has been made possible by the fact that the advertising receipts have been larger than was anticipated. The advertising receipts, whatever they may amount to, go to the support of the newspaper, together with a regular cash appropriation of $\$ 700$ a week from the city treasury.

George H. Dunlop. ${ }^{1}$ 